\title{
OBSERVATIONS ON THE ORIGIN AND DEVELOP. MENT OF THE IDEA OF JUSTICE
}

\author{
ALEXANDER H. KRAPPE*
}

7 HE term justice, like the Latin iustitia from which it is derived, is currently used in two acceptations, to wit: (I) as a designation of that state of affairs which a given society regards as the good one, that state in which things are done as they ought to be done, the state of harmonious, peaceful relation between individuals, the individual and the social group of which he is a member, several social groups, and, furthermore, between individuals or social groups and certain higher powers whose existence is assumed, as well as, finally, though with certain restrictions, ${ }^{2}$ between human individuals and certain members of the animal kingdom, and (2) as a convenient term for a general disposition on the part of individuals, social groups, higher powers, or animals to maintain or help bring about this state of perfection. In the classical definition of Thomas Aquinas, taken from the Digest," that "Justice is a habit according to which, by a constant and perpetual will, we give to each his due," the term justice is clearly used in the second of the two acceptations. ${ }^{4}$ But it is equally clear that the second meaning wholly depends upon the first-so much so that without the one the other would not exist. For the purpose of the present study it is therefore sufficient, in order to clear up the exact nature of this state of perfection, to trace it, if possible, to its roots or to one of its roots.

From the definitions attempted above, it follows that the concept presupposes a more or less complicated social organization composed of members whose rights, while not necessarily equal, ${ }^{5}$ are nonetheless well de-

* Université de Bruxelles.

- ${ }^{x}$ For a good outline of the concept and its evolution in Western civilization in classical and Hebrew antiquity cf. Gurvitch, 8 Encyclopaedia of the Social Sciences, 509 ff. (1932).

a The question whether the lower animals had claims upon our justice and mercy as men did or whether they were of no account, owing to their different nature, was the subject of debates among the Stoic doctors. Cf. Diog. Laert., VII. I. I25 f.; X. I5०. The Roman Catholic Church acknowledges no obligations of man to animals.

3 Digest I:4: "Iustitia est constans et perpetua voluntas ius suum cuique tribuendi."

4 It is in this sense, too, that Edward Westermarck employs the term; cf. his work, The Origin and Development of the Moral Ideas, vol. I, p. I28 (I9 I 2-I7).

5 Husserl, 47 International Journal of Ethics 284 (I937), properly pointed out that the idea of equality is foreign to many communities governed by tradition; but he failed to stress that a state of inequality willingly accepted and duly regulated by law and custom, while not the 
fined and generally acknowledged by the group as a whole. Thus there may be justice among the fowl of a barnyard, the bees of a hive, and between a cat and a dog living in the same household; but there can be no justice between wolves and sheep, for the latter have no right acknowledged by the former; the two are in a permanent status belli. To call the wolf 'unjust' because of its avowed fondness for mutton and its frank and open manner of obtaining it, is therefore a bad logical lapse. Justice is by no means of universal application but a state possible only among certain well-defined organisms or groups of similars; its importance lies solely in the fact that Homo sapiens happens to be one of these.

Justice is then the most perfect expression of harmonious relation between individuals or social groups living in peace and friendship with one another on the basis of the freely acknowledged rights of each. Injustice means the denial or abrogation of those rights, that is, the negation of the very foundation upon which such a society is built, and hence necessarily leads to its speedy dissolution. This sufficiently explains the vast importance of the mechanism required to maintain it and to bring it about where it did not exist previously, i.e., where a society is just being organjzed, or to improve and perfect it. This holds true for all social organizazations-savage tribe, religious community (ecclesia), village community, polity, and the modern state. As is well known, most of the troubles from which the world is suffering at the time of this writing are owing to the absence of the corresponding mechanisms as applied to sovereign states.

From what has been said it is also clear that the yearning for such perfect relations as can be honored with the term of justice must antedate all complex social organisations, since without it they could not have been constituted in the first place. It is therefore bound to exist even in the most rudimentary forms of society, and to be a basic trait of human character, something quod semper, quod ubique, quod ab omnibus. In fact, it cannot be separated from the basic truth, recognized by Aristotle and badly neglected by J. $-\mathrm{J}$. Rousseau, that man is a civic animal. To get at its root we must leave aside all the refinements which complex civilizations have imparted to the ancient concept, and must observe its manifestations among the simple societies of the semi-civilized.

Mindful of the well-known experience that all symbols are of considerable, often of a truly venerable, age, we recall that the symbol of justice

most perfect state conceivable in the absolute, is not in itself a state of 'injustice'-at least not so long as law and custom are properly observed and enforced, so that every one, high and low, receives his 'due.' The Venetian oligarchy, to quote only one example, was certainly not grounded on any idea of 'equality'; but no one will deny that there was 'justice' in Venice. 
is the balance, a form of symbolism which may or may not be older than the rise of trade in the great river valleys. At all events, it expresses the idea of reciprocity and seems to indicate that reciprocity is an essential, perhaps the most essential, element in the complicated concept of justice. Historical and anthropological research has presented us with innumerable illustrations from the simple societies of the semi-civilized. ${ }^{6}$ Since Edward Westermarck in his classical work for some reason fails to bring out this basic fact, a presentation of some of the more striking of these illustrations may prove helpful.

As is generally known, the exogamic marriage predominates over a large part of the earth's surface: This simply means that the wife is chosen from another social group. This implies in practice that group B cedes a girl to be the wife of a member of group A, thus voluntarily depriving itself of an economic asset represented by the girl's power to do productive labor, in favor of group A. This is so far recognized by the latter that an equivalent is offered in return. ${ }^{7}$ This equivalent may take various forms, viz.: ( $\mathrm{x}$ ) a payment in kind (cattle) or cash; (2) a girl of group A given to a member of group $\mathrm{B} ;$ (3) a certain amount of work performed by the prospective husband for the bride's father or brother, i.e., for group B. ${ }^{9}$ As most readers will recall, it is in this manner that in the biblical narrative Jacob 'earns' his two wives.

Such are three among the 'just' methods of entering upon the holy state of matrimony. As may be surmised, there occasionally occurs a less 'just' procedure, which consists in the rape or abduction of the bride with or without her consent. That this procedure was once fairly widespread in the ancient world may be safely concluded from such famous cases as the rape of the fair Helen, the abduction of the Sabinian women by the Romans, etc. ${ }^{\text {I0 }}$ It is interesting to note that the existing narratives of these events make it clear that they were essentially 'unjust,' inasmuch as they were not directed against an enemy, i.e., a party to whom no sort of obligation was owing, but against parties on a footing of peace and friendship.

6 The honor of having, in modern times, brought out fully the importance of reciprocity in social relations goes back to the French scholar Marcel Mauss, Essai sur le don (Année sociologique, nouv. série, t. I, I923-24), Paris, r925, pp. 30-186, and to the German anthropologist Thurnwald, Die Gemeinde der Bánaro, esp. p. xo (Ig2r).

${ }^{7}$ Lévy-Bruhl, The "Soul" of the Primitive 99 ff. (Ig28),

8 James, An Introduction to Anthropology I23 (Igrg): "The simplest, and therefore perhaps the commonest method of procedure is to exchange a sister for a wife." Cf. also Lowie, Primitive Society I8 (1920).

9 Sir James G. Frazer, 2 Folk-Lore in the Old Testament 342 ff. (I9I8).

${ }^{20} \mathrm{M}$ cLennan, Studies in Ancient History 3r ff. (r886). 
In the case of Helen, Paris was bound to Menelaus by the ties of hospitality; in the case of the Sabinian women, Romulus had solemnly proclaimed a state of peace in connexion with the games to which the Sabines had been invited. The outcome of these tales leaves no doubt about the true sentiments of the societies for which they were written or recited; it means that public opinion did not approve of the procedures adopted.

This tallies with the attitude of present-day semi-civilised societies, among whom violence is not ordinarily resorted to. If asked why it is not, the usual (and doubtless correct) answer is that such a procedure needlessly complicates matters: clan B considers itself 'wronged,' i.e., deprived of something intrinsically its own, without a fair equivalent being offered in return. The least that may therefore be expected to happen is that it reacts by abducting a woman of clan A. Unfortunately, violence is usually apt to lead much farther than was originally contemplated, and there result 'complications,' involving slayings or mutilations. That is why marriage by capture is frowned upon in most semi-civilised societies, and, when it does occur, is speedily settled either by the return of the woman abducted or by the offer of a fair equivalent, which may assume any of the three forms mentioned above." Justice, at all events, means perfect reciprocity between such social groups as formally recognize each other's rights and who in most cases have established what the Latin jurists called connubium between each other.

An even more striking example of this reciprocity is furnished by intertribal slayings. It has often been pointed out that the primitive view does not draw a demarcation line between intentional and unintentional slayings; that crime and tort are not differentiated. The semi-civilised man is content with looking at the simple fact, which, to his clan feeling and clan consciousness, means an undeserved loss for the group resulting from the slaying of a useful member.

Here it is well to remember that 'useful' is by no means the mere equivalent of 'productive' in the sense of modern economics: it means in fact considerably more, for to the value of a man in collective fishing, hunting, grazing, gardening, and primitive tillage (and in semi-civilised societies these activities are largely collective) there must be added the prestige value which is inevitably conferred upon a social group by its mere number. A slaying, whether accidental or intentional, means a reduction of its power from the economic and political viewpoint; it is calculated to disturb the balance of power existing between rival clans. Hence the necessity of 'redressing' this wrong in any one of a number of ways.

Ix Letourneau, The Evolution of Marriage 9r ff., xo7 (I895). 
One of these, perhaps the most obvious one, is that of weakening the slayer's clan correspondingly by slaying one of its members, preferably the slayer himself, who is thus the equivalent of the man slain..$^{22}$ The disadvantage of this method is very much the same as the one observed in connexion with the rape of brides: it leads to complications, as violence is apt to have consequences difficult to foresee and to carry both parties to a dispute further than they had originally intended to go. ${ }^{13}$ For this reason the desire to 'compensate' for a slaying by the offer of a fair equivalent arose at a very early stage, first, no doubt, in cases where the slaying was manifestly unintentional and purely accidental. This compensation may take one of several forms. It may consist of the delivery to the clan wronged of a price, in kind or in cash, which by agreement is deemed sufficient to indemnify the group injured for the economic and prestige loss sustained. This is the origin of the well-known institution called wergild, bloodfine, etc., and which appears to be common to all humanity, except in so far as it has been replaced, in the ancient and modern civilisations, by more perfect forms of atonement.

It may take a more peculiar form still: the slayer may surrender to the hostile clan, to be adopted by it, thus taking the place of the man slain and placing his own productive labor at the disposal of the clan injured by the slaying. Among certain North American Indians, for example, the feelings of a desolate mother, whose son had been brutally murdered, were assuaged by adopting the murderer in place of her slain son. ${ }^{14}$ Among the Kabyls of Algeria a person who had killed another unintentionally, went to the parents of the slain, saying: "If you wish to kill me, kill me; here is my winding sheet. If not, pardon me, and I shall henceforth be one of your children." From this day on the manslayer was considered to belong to the kharouba, or gens, of the deceased.25

Similarly, a widow whose husband had been murdered, might be consoled by marrying the murderer. ${ }^{36}$ Some readers may recall an episode of the Old French romance of the Chevalier $d u$ Lion, in which this very contingency arises: the hero takes the place of the knight whom he has slain in combat, and marries the widow who, the poet is careful to point out, is

x2 We intentionally disregard here, of course, the emotional element, which in many cases probably plays an even larger part than mere calculation.

${ }_{3}$ Cf. Tacitus, Germ., c. 21 : nec implacabiles durant: luitur enim etiam homicidium certo armentorum ac pecorum numero recipitque satisfactionem universa domus, utiliter in publicum, quia periculosiores sunt inimicitiae iuxta libertatem.

$\therefore$ Letourneau, op. cit., $29 x$.

${ }^{25} 3$ Hanoteau et Letourneux, La Kybilie 68 f., cf. I Westermarck, op. cit. 484 .

${ }^{26} 2$ Briffault, The'Mothers 353 (x927). 
clearly in need of a protector. It is not necessary to explain this story by the assumed model of the Rex nemorensis of Golden Bough memories or by equally hypothetical influences of the ancient Milesian tale of the Matron of Ephesus. It merely reflects a state of society and a conception of justice based upon strict reciprocity which, in Europe, had long ceased to exist when the romance was written down in the twelfth century, but which are found to the present day in many a semi-civilised society.

Among the Habe hill-men of the French Sudan a murderer is expected to supply the family of the victim with a woman from his own family; when she bears a son, the boy is given the name of the murdered man, and the two families are once more on the best of terms. ${ }^{17}$ Among the Jâbla of Northern Morocco one who has committed a homicide sometimes induces the avenger to abstain from his persecutions by giving him his sister or daughter in marriage; and a similar custom has been noticed among the Beni Amar and Bogos. ${ }^{18}$ In other cases slaves are given to the relatives of the slain to atone, i.e., to compensate for the guilt. ${ }^{19}$

Much the same considerations are at the bottom of the ius talionis, the endeavor, that is, to exact from the offender an atonement which not only corresponds to the injury in the degree of gravity, but which is its exact equivalent in what would appear, to our way of thinking, the most insignificant details. It is for this reason that the Germans have replaced the Latin term by the word Spiegelstrafe, ${ }^{20}$ thus intimating that the atonement reflects the injury as a mirror reflects an object. It is quite likely that there are some mystical considerations at the bottom of this institution, namely, the idea of a nefarious action, resembling a spell, which can be annulled and neutralised only by a like action but exerted in an inverse sense. ${ }^{2 x}$ In the main, however, the ius talionis is merely the expression of the same conception of justice as absolute reciprocity. As such it is known all over the earth, among the ancient Babylonians and Hebrews no less than among the Iroquois of the New World.22 The punishment may assume degrading and repulsive forms. Thus in the case of adultery committed by a married man the New Caledonians practice a singular retaliation: the adult men of the village simply violate the wife of the delinquent. ${ }^{23}$ As is generally known, some representatives of Jewish theology in Hellenistic

17 Arnaud in 3 Revue d'ethnographie et des traditions populaires 249 (x922); cf. Briffault, op. cit., I, 353, n. 3. On the whole subject cf. also Kropotkin, Mutual Aid I34 (rgo2).

\footnotetext{
${ }^{18}$ I Westermarck 484.

${ }^{x}$ Tbid.

${ }^{20}$ Viz., "mirror punishment."

${ }^{2 x}$ Lévy-Bruhl, Le surnaturel et la nature dans la mentalité primitive 502 ff. (I93I).

${ }^{22} 5$ Thurnwald, Die menschliche Gesellschaft IIO and I6I (I93I-34).

${ }^{23}$ Letourneau, op. cit. $209 \mathrm{ff}$.
} 
times attributed to the deity the same considerations of purely human reciprocity relations, insisting that every evil-doer is punished here on earth by a misfortune which corresponds even in insignificant details to the fault committed. Thus in the Book of Jubilees, Cain, having slain Abel with a stone, is in turn killed by the stones of a collapsing house. ${ }^{24}$

Bearing in mind that the overwhelming majority of cases in litigation involve questions of interest, it would seem logical to test the correctness of the views just set forth by an examination of the role of justice in 'primitive' economy. As is now generally known, thanks to the researches of Marcel Mauss, ${ }^{25}$ Malinowski, and other anthropologists, exchange in semi-civilised societies largely assumes the form of gifts. These are however not gifts in our sense of the word, as the donor definitely imposes upon the donee the obligation to return the equivalent of the gift at an early opportunity, if not at once. As has long been known from the accounts of travellers, no stranger may approach a chief unless prepared to make him a present. ${ }^{26}$ It is also well known that the chief is then supposed to reward the giver with a present of his own, which should be (and often is) the equivalent of the gift proffered. Such an exchange of gifts establishes peaceful and friendly relations between the two parties. ${ }^{27}$

Now it is worth noting that the chief is obviously not forced to reciprocate the stranger's present. If he does so, the reason is that failure to do so would constitute a gross breach of good manners, calculated to diminish his prestige in the eyes of his own people, as liberality is one of the most outstanding virtues required and expected of a chief. There also seems to have lingered a belief that a gift had an obscure power of its own, likely to work harm on the donee unless reciprocated. ${ }^{28}$ At all events, a disappointed stranger could most effectively revenge himself by satires upon the offender, magic songs, that is, which struck the person against whom they were uttered with illness or other misfortunes. Irish traditional lore is full of instances of this type. ${ }^{29}$ Even after the belief in the super-

24 Bousset, Die Religion des Judentums im späthellenistischen Zeitalter 4 II ff. (r926).

25 Op. cit., supra, note 6.

${ }^{26} \mathrm{It}$ is even now a prescribed custom at the courts of some Indian princes never to approach the monarch empty-handed, however trifling the present may be.

${ }^{27}$ The true nature of the 'gift' is still seen in the old German law rule by which a gift cannot be revoked once a return gift has been accepted. A similar provision has been noted in the law of Islam; cf. I Kohler and Wenger, Allgemeine Rechtsgeschichte 99 (I9I4) (Die Kultur der Gegenwart, II, 7 [I]).

${ }^{28}$ Mauss, op. cit., supra, note 6, at 47 .

${ }^{29}$ Robinson, Satirists and Enchanters in Early Irish Literature, in Studies in the History of Religions, presented to Crawford H. Toy, New York, Igr2, pp. 95-130. 
natural power of such satires had passed, there remained their effect upon 'the chief's prestige, his honor, his good name. As a matter of fact, we know from the Icelandic sagas and the Teutonic epic that the same custom once existed in Northern Europe and that kings and jarls feared nothing more than the evil repute of miserliness. ${ }^{30}$

The exchange of goods and services moves on the same level. The ancient Scandinavian hird, like the retainers of an Irish or Scottish chief, did not serve for fixed wages or stipends. But they sat at the chief's table and slept in the chief's hall, and the chief was expected to bestow gifts, usually in the form of golden bracelets, upon them on special occasions. In the moving narrative of the death of St. Olaf, king of Norway, in the battle of Stiklestad (rozo A.D.), his court skald brings out the significant fact that the king had taken good care of his men and had fed them well, whence their willingness to die for him and with him. On the other hand, a miserly king cannot count upon the devotion and loyalty of his men; such a king is 'unjust,' and the absence of justice here means an absence of that reciprocity in gifts and services which formed the basis of economic and political life in ancient Scandinavia.

On quite a different level, and certainly in an entirely different environment, we have the Melanesian mapula, or payment made by the husband to his wife at frequent intervals, which is frankly declared to be the equivalent for the sexual services rendered by the wife; for the same term also denotes the payment made by men to unmarried girls (who enjoy considerable license) for a like service. ${ }^{3 \mathrm{I}}$

What is true for the ancient Scandinavians is no less so for all Teutonic peoples down to the period of the migrations and beyond. The Teutonic king's treasure (Schatz) served no other purpose than to store the gifts which had to be distributed among the followers to keep them loyal and devoted to the prince. ${ }^{22}$

This insistence on reciprocity is so strong that in cases where by the very nature of the transaction the return present became invisible and intangible, though by no means imponderable, a symbolic or 'token' present was given in return. For example, in societies where taxes take the form of gifts presented to the executive, that is, to the chief or king, the latter is

${ }^{30}$ Quite naturally, this feeling of obligation can easily degenerate into a desire for mere ostentation, the endeavor to outbid the other party in generosity and liberality. This comes out in the "potlatches" of certain Indian tribes of British Columbia, which have frequently been commented on.

${ }^{3 x}$ Malinowski, Argonauts of the Western Pacific I79 (rg22).

${ }^{2}$ Dahn, Urgeschichte der germanischen und romanischen Völker, vol. I, pp. 484 ff. (I88I); and vol. IV, pp. 55 ff. (I889). 
not supposed to let the taxpayer go away empty-handed, but he will invariably offer a gift in return which, though obviously not the equivalent of the gift offered, is so at least symbolically. The facts underlying this institution are evidently these: the true equivalent of the gift offered is exactly the same as that which accrues to the tax-payer of modern societies, namely, good government, individual protection by the police and by the courts, etc. But this equivalent, though very real, is nonetheless invisible. Thus it might appear that the monarch receives a gift without giving a fair, i.e., visible, equivalent. To obviate this unfavorable impression, he makes a symbolic present to the party offering the gift, i.e., to the tax-payer.

The same view, and the custom that has grown out of it, survived into the feudalism of the European Middle Ages. There a freeman who made over his property to a lord did so for real and very considerable advantages, the lord's protection, a very important matter in a lawless age, but invisible all the same. His gift would thus have appeared one-sided. To avoid this erroneous and highly undesirable impression, the lord returned a symbolic present, some object of little value, a glove for example, which was the pledge of the liege lord to protect his liegeman in return for the gift.

Much has been written in opposition to the views set forth in J.-J. Rousseau's Contrat social and that philosopher's theory of the State. As the historical school of F. K. von Savigny had no difficulty in pointing out, this theory suffered from over-simplification of a thorny problem and from a considerable ignorance of anthropological data. It is of course absurd to suppose that primitive communities were formed by constituent assemblies. All social organisations of this type are rather of slow growth and have their raison d'être in the fact that man is a civic animal.

All this may be readily granted but cannot alter the fact that Rousseau was fundamentally right: the essential basis of all social organisms, from the primitive community to the modern State, is an implied contract between the governors and the governed. ${ }^{33}$ The Melanesian chief who receives large offerings of yams and other produce at harvest time, is not supposed to keep these for his own exclusive use but is bound to redistribute them among the tribesmen on stated occasions. The Teutonic (and also the Homeric) king received offerings in the form of gifts; in return he had to exercise very important functions; being thought divine, he was held responsible for fair weather and good crops. Crop failure and famine

33 “. . . . the whole of society seems built, if not upon an original explicit contract, as Rousseau imagined, at least upon a quasi-contract . . . " Gide and Rist, A History of Economic Doctrines 596 (Boston, n.d.). 
spelt his doom; the ancient Swedes, for example, concluded that in such an event he could not or would not exercise the functions expected of him, and they killed him outright.

An invisible, intangible, and furthermore imponderable character is peculiar also to man's economic transactions with the higher powers, be they deified ancestors or gods. Man is as a rule quite certain of the services he wants those powers to perform for him. He also knows that in fairness he cannot expect them to perform them for nothing. This consideration is at the bottom of the do ut des form of sacrifice. ${ }^{34}$ The offering had to be a fair equivalent of the favor expected; among the ancient Semites it could go so far as the offering up of the first-born. To placate the powers having control of a piece of land to be used as building ground, itwas necessary to offer a foundation sacrifice, a custom well known all over the Old World and also in Oceania. No religion has ever gone so far, in the exact definition of what was 'due' to the gods, as did that of the ancient Romans; they more than any other race seem to have been aware of the strict reciprocity relation which must exist between gods and men. At any public calamity, a lost battle, a failure of harvest, a pestilence, an earthquake, they therefore concluded that this reciprocity relation had been disturbed, that the gods had not received what was their 'due,' and they promptly went to work with lustrations, lectisternia, games, propitiatory sacrifices, etc., to appease the irate divinities by giving them their 'due' and, if need be, even more than their 'due.' In other words, the Romans, who are known to have been the most legalistic people, i.e., the most meticulous in the maintenance of a just balance and correct reciprocity relation in mundane matters, carried the same principle over into the realm of religion.

Protestant travellers in Southern Italy and Sicily have often been scandalised at seeing the peasant populations mistreat their saints if their prayers remained unanswered. What these observers did not realise was that to the peasant a prayer is not merely a prayer, i.e., a request, but a service, as it is usually accompanied by some offering. He therefore feels that he has a right to expect a return in the form of the 'avor sought. Failure to receive a satisfactory answer to his offering therefore means a gross breach in the reciprocity relation postulated. The saint is found remiss in the obligation contracted when he accepts the offering; hence the indignation of the worshiper. His action betrays no particular depravity or impiety but is simply the carrying over, into the saints' cult of the Ro-

34 von Nègelein, Die Idee des Aberglaubens 33 (I93I). 
man Church, of the ancient reciprocity relationship between gods and men postulated by the ancient Mediterranean religion. ${ }^{35}$

There comes a point in the history of most religions when the obligations (or some of them) due to the higher powers are replaced by obligations due to one's fellow-men: "Inasmuch as ye did it unto one of these my brethren, even these least, ye did it unto me." ${ }^{36}$ Brahmanism and Buddhism had preceded Christianity in this, and Islam was to follow six centuries later. Thus among the Haussa of the Sudan, where the ripening of the grain harvest is accompanied by seasonal fevers, it is customary to distribute this grain among the poor to be spared the disease. ${ }^{37}$ The basic idea is that the higher powers have a right to expect a fair return for the crops they have granted. This equivalent is given to the poor in the form of alms, and thus the equilibrium in the delicate reciprocity relationship between the higher powers and man is restored. This view, strange as it may seem to modern sentiment, is strikingly confirmed by the semantic development of the Hebrew word zedaqa, 'alms' (Arab. sadaqa). The original meaning of this word was 'justice'; but in Hellenistic Hebrew and in Arabic it means not only this but 'alms,' 'bride price,' and even 'tax.' The common denominator of all these acceptations is simply 'obligation,' 'due,' and as such it denotes any kind of action designed to restore the equilibri$\mathrm{um}$ in a reciprocity relationship, which is 'justice. ${ }^{3^{8}}$

The 'offering' which preceded, as we have stated, the custom of giving alms, did not necessarily assume a ceremonial form. A man might try to restore the equilibrium disturbed by some great favor shown him by the higher powers by simply divesting himself of, or outright destroying, part of his possessions. Many readers may recall the story of the ring of Polycrates, thrown into the sea by the tyrant of Samos anxious to appease the 'powers,' but recovered by him in a fish caught by his men, a clear token that the 'powers' had declined his offering and decided upon his doom. ${ }^{39}$ As a matter of fact the 'Nemesis,' the 'envy of the gods,' mentioned in the ancient writers is nothing but a convenient expression to denote the dissatisfaction of the higher powers with the disturbed equilibrium of the reciprocity relationship existing between them and mankind.

This reciprocity relationship is not limited to the exchange of goods and (I 898 ).

${ }^{35}$ Homer, Iliad, vol. I, 33 ff.; cf. also Meyer in 5 Zeitschrift für Kulturgeschichte 24 ff.

\footnotetext{
${ }^{36}$ Matt. xxv. 40. 37 Mauss, op. cit., supra, note 6, at 58.

${ }^{38} \mathrm{Cf}$. also Bousset, op. cit., supra, note 24 , at 380 .

39 Stith Thompson, Motif-Index of Folk-Literature, L 4I 2.I; N 2I I.I.
} 
services; it is the basis of the entire system of hospitality, such as it is known to exist among the semi-civilised. There hospitality is not an individual affair but is decidedly collectivistic. It is not one individual who calls on another individual, but a whole community which visits another community and is hospitably received by it. This institution of 'group hospitality' as it may be called had been observed among the Andaman islanders, the Melanesians and Polynesians, the Indians of the American Northwest, and many other populations..$^{\circ}$ The hospitality of the ancient Germans as described by Tacitus ${ }^{4 \mathrm{I}}$ appears to have been of the same type. ${ }^{42}$ Certainly, the expedition of the Burgundians to the court of King Etzel shows that this 'group hospitality' was lingering on, in folk memory, down into mediæval times. The German name for such festivities seems to have been Hochzeit, the meaning of which has now been restricted to 'wedding.'

This hospitality is however no one-sided affair. On the contrary, it is a strictly reciprocal matter. Community A invites community B, entertaining it lavishly, not only with food and drink, but with women (sex hospitality), clowns and theatrical performances, games, in short, with everything that the heart can desire. Any attempt to economise would be altogether out of place and merely redound to the shame of the community showing such ill-breeding, and it is the particular obligation of the chiefs to see to it that nothing is wanting. Nor does the matter end there. When the time of leave-taking comes, lavish presents must be given to the guests, to take home with them, as a token and remembrance of the hospitality shown them. The equilibrium of the reciprocity relation between hosts and guests, which has thus been disturbed in favor of community B, is however restored at a shorter or longer interval by an invitation of the latter extended to community $\mathrm{A}$, which is of course accepted. Then an effort is made to entertain the erstwhile hosts even more lavishly and to present them with gifts which, if possible, outshine those received in the first instance.

In acting thus, community B is not under any sort of compulsion; it is simply a question of keeping up its good repute, and for its leaders it is a question of upholding their honor. To act differently would be dishonorable; the good name of the community would be lost; it would be subject to jibes and satires; it would sink into a status of inferiority.

Under certain circumstances it may be impossible to reciprocate immediately a gift received, a service rendered, or hospitality shown. In that

${ }_{40}$ Mauss, pp. 6 I ff. ${ }_{41}$ Germ. c. $2 x$.

${ }^{42}$ The last phrase of the passage, however (sed nec data imputant nec acceptis obligantur), is certainly erroneous and probably due to incomplete information. 
case it is necessary to make a 'token payment,' a basi (to use the Melanesian term), which conveys to the donor the donee's sense of obligation with his good-will to acquit himself of it at an early opportunity; but it does not restore the equilibrium; it merely postpones the definite settlement. ${ }^{43}$

To realise to what extent this exchange of 'gifts' is really the forerunner of contractual relations, it is interesting to examine the exchanges going on between agricultural and fishing communities among the Maoris of New Zealand. This exchange has been individualised to the extent that each farmer has a partner among the fisher folk. At harvest the farmer deposits his produce before the fisherman's hut. Conversely, the fisherman, after a successful haul, will restore the balance, and generously so, by taking his catch to the farmer's house. ${ }^{44}$ The system works in much the same manner as an implied contract enforced solely by the 'honor system.'

Services may be exchanged for hospitality. As is well known, housebuilding is a collective affair among many so-called primitive people, e.g., the Maoris of New Zealand and the Polynesians generally. It was so even in many parts of Europe and the Near East down to relatively recent times. ${ }^{45}$ The entire community collaborates in the building of the chief's 'big house,' but when the task is completed, the whole community is invited to partake of the feast given by the chief and at the chief's expense, presents being distributed among the guests before the meeting breaks up. ${ }^{46}$ In the writer's own childhood it was still customary, in parts of France and the Rhine country, at the completion of a house, to invite the masons, the neighbors, and, usually, the village priest, to a banquet given by. the owner or entrepreneur, a custom which has been plausibly interpreted as a survival from a stage of economy in which the workmen did not receive fixed wages but worked with no other expectation than the owner's hospitality and parting gifts of commensurate value.

It must be clear that such a system of give and take is in many respects the very opposite of the system governing modern commercial exchange. The latter may well be summed up by a little rhyme going back, it seems, to the time of Cromwell:

In matters of trade it's a fault of the Dutch

Of offering too little and asking too much.

43 Mauss, p. 75.

4 Ibid., p. 8I; Malinowski, Crime and Custom in Savage Society 22 (I926).

45 Bücher, Arbeit und Rhythmus 3 II and 333 (I9r9).

${ }^{6}$ In Melanesia, the leader of an expedition or entrepreneur in an industrial venture gives a feast with a distribution of gifts to the guests. Those who participate in it and accept the gifts offered are then bound to take part also in the venture and to assist their host throughout the enterprise; cf. Malinowski, p. 6r. 
Under the system we have been discussing, the point is to offer more in return than was received in the first place and to do so for the sake of 'honor' or 'prestige.' Even without the ancient Scandinavian texts to which reference has been made above, we should conclude that this system once prevailed in the Celtic and Teutonic worlds; for it appears in the Middle Ages, where the queen of virtues was liberality.47

It has sometimes been asserted that this virtue was extolled by the minstrels, who were the chief beneficiaries, and that their verses reflect the views of their caste rather than those of the nobility. If that were true, one could not help admiring the thoroughness with which their teaching took effect and the docility with which the nobles and princes made this doctrine their own. The real cause of this attitude, so different from our own, goes much deeper, and must be sought in the perpetuation by the European nobility-largely of Teutonic blood-of the old system of give and take, which consisted in a sort of rivalry in generosity and liberality, a system still well known in the islands of the Pacific and among the Indians of the American Northwest.

This rather primitive mode of thinking has left behind curious survivals in the midst of modern thought patterns. There is, for example, the biblical passage of the thousand-fold reward in the other world (and sometimes even in this one) for some act of kindness shown, a doctrine exemplified by many pretty stories inserted by the mediæval preachers in their sermons..$^{8}$ It required the rationalism of the eighteenth century and the sober spirit of a Benjamin Franklin ${ }^{49}$ to show that, like most survivals, this mode of thinking had become an absurdity.

It is well worth noting, however, that this evident absurdity was once far less absurd. Like all economic systems, this primitive system of give and take could flourish only so long as it enjoyed a certain universality. The prince could afford to be liberal so long as his liberality extended to all 'guests,' whether they were subjects or strangers. For only in that case was the equilibrium restored and no one suffered. The system ceased to function properly the moment the prince limited his liberalities to his minstrels, his artists, and his clowns, while his subjects received nothing in return for their gifts, i.e., their taxes, except an inefficient government.

${ }^{47} \mathrm{Cf}$. Whitney, Queen of Mediaeval Virtues: Largesse, in Vassar Mediaeval Studies I8I-215 (I923).

${ }^{48}$ Cf. 39 Bulletin hispanique 25, Nos. I39-4I (1937); Koran, sur. LXIV, I6-I7.

${ }_{49}$ " $\mathrm{He}$ that for giving a draught of water to a thirsty person should expect to be paid with a good plantation, would be modest in his demand compared with those who think they deserve Heaven for the little good they do on earth." 
The prince then became 'unjust,' because the reciprocity relation was disturbed without being redressed, having become one-sided. It is to this that Machiavelli adverted in a noteworthy chapter of his Prince, ${ }^{50}$ which also marks the beginning of a new epoch in the history of European political economy.

Liberality was extolled in still another part of the world and in the midst of a civilisation vastly superior to that of mediæval Europe: the Near and Middle East at the time of the crusades, where the noble Hatim Tai and the generous Saladin have remained models of generosity down to the present day. ${ }^{5 x}$ There, too, we are no more dealing with a heritage from the Orbis Romanus or the Empire of the Sassanids than we are in mediaeval Europe. It is rather the survival of a system which flourished among the pre-Islamic Arabs, who were in the same stage of civilisation as certain peoples of Northern Europe before their contact with the Romans. It remained alive among the Arab aristocracy even under the Khalifs, and the Seldjuk princes, of whom Saladin was one, adopted the ideals of the Arab nobility.

The ancient institution we have reviewed may shed some light on the origins of a well-known concept of the English common law, namely the concept of consideration, without which, as is generally admitted, there can be no obligation. As late as the eighteenth century a consideration was defined as 'a past service rendered with the promisor's consent and with an expectation known to him of reward as justly due." ${ }^{22}$ As is also known, the force of the concept has been progressively restricted in decision after decision, and the modern doctrine of consideration rejects moral obligation as a sufficient consideration. But this merely proves that the concept of 'moral obligation' itself has been losing its ancient force, as have such concepts as 'honor,' 'prestige,' etc.-so much so that to express the feeling engendered by their loss we have been obliged to have recourse to an Oriental term and to speak of a loss of 'face.' Originally 'consideration' was the gift bestowed or the service rendered by party A with the implied understanding that party $B$ would render the equivalent therefor at an early opportunity; it was the act by which the equilibrium of the reciprocity relation between the two parties was disturbed in favor of party $\mathrm{B}$, placing the latter under an obligation to redress this equilibri-

${ }^{\text {so }}$ Cap. 16. Machiavelli's observations are derived from Cicero, De off., I. I4. 42-43.

$5 x$ " $L$ 'argent ne reste pas dans la main des hommes généreux, ni la patience dans le cœur d'un amant, ni l'eau dans un crible," Sadi, Gulistân, I. I3.

${ }^{52}$ Sir Frederick Pollock, Principles of Contract 169 (I889). 
um by an equivalent gift or service. The concept therefore seems to go back to a time when the Anglo-Saxons followed much the same system of give and take which we see still functioning among the semi-civilised of four continents. The consideration engenders the obligation; it resembles the German Angebinde, i.e., a gift the acceptance of which by the donee puts the latter under an obligation to make a return gift of equal or greater value, with a view to restoring the equilibrium of the reciprocity relationship. .3

The essential fact that we must never lose sight of is the absence of legal coercion and the functioning of an 'honor system.' It is enforced by a desire to keep one's prestige, one's social position, one's good repute, and by the fear of losing 'face,' of appearing petty, miserly, contemptible in the eyes of the neighbors and of the village community. But even after this 'honor system' has given way to strict legal forms and sanctions the old feeling does not disappear, or disappears only gradually. Atonement for misdeeds, virtually considered as simple torts, is due to the party wronged, so as to restore the equilibrium of the reciprocity relationship. Only when this obligation is fulfilled and the equivalent accepted, does the offender feel again free and easy, the social equal of any one of his fellow-tribesmen. But even after this private mode of settling conflicts has been superseded by settlement in a court of law or by the arbitration of a chief acting as umpire, the reaction of the individual offender remains the same: a breach of any of the rules underlying the reciprocity relationship produces remorse, which can be overcome only by a settlement of the dispute and the restoration of the disturbed equilibrium:

When a Kafir has injured a man, he feels ill at ease until the chief makes him pay a fine. Thereupon he feels relieved in mind. Before he paid the fine he would not dare look his fellows in the face; having paid it, he is as good as any man he may meet in a day's march. Or he may have committed adultery with another man's wife. He feels guilty until he has made restitution by paying an ox. Affer that he feels quite comfortable. ${ }^{54}$

Remorse is perhaps too strong a term to describe the feeling referred to; it is rather one of discomfort, comparable to the one experienced by a white man conscious of having-given too small a tip to the steward who took care of him during a spell of seasickness, that is, a feeling resulting

\footnotetext{
53 The binding force of this system of mutual services, of give and take, extending over long periods of time, and its importance in primitive society, were recognised and admirably formulated by Malinowski, p. 67.
}

54 Kidd, The Essential Kafir 258 (I904). 
from an analogous breach of the rules at the bottom of a reciprocity relationship.

The custom law of the semi-civilised rarely fixes the time which may elapse between give and take, chiefly, no doubt, for the excellent reason that such societies are properly societies that time forgot. But it is clear that this interval must never be so long as to allow the gift or service which is to be reciprocated to be forgotten, or to make it likely that a considerable number of the participants have passed away. In other words, the time factor does play a very definite role in these reciprocity relationships.

It frequently happens that, in the course of time, the basic conditions of this reciprocity relationship become fundamentally different. It may happen, for example, that the service rendered for a gift becomes wholly illusory, losing all meaning with the passing of time. To quote an obvious example, the commendatio of the feudal system preserved its character of reciprocity only so long as there was no strong State to protect the small freeholder. When royal authority reassertéd itself, as happened in Europe in the course of the fifteenth century, there was no longer any need for the liege lord's powerful arm to protect his liegeman. Yet the feudal servitudes assumed at the time of the commendatio remained in force. Thus the old reciprocity relationship was lost, and this loss was keenly felt by the losing party, i.e., the tenants, who resented the system as a gross injustice. It may have been the Parisian mob which in 1789 started the French Revolution; what fanned it and kept it going was this bitterness of the French peasantry, which refused to redeem the servitudes by compensations claimed by the beneficiaries. The peasants felt-no doubt rightly-that whatever services had once been rendered by the feudal lords had been fairly compensated by centuries of servitude.

Reference has been made above to the obvious fact that the delicate sense of a perfect equilibrium in the reciprocity relations between two parties is a necessary outcome of all social life. We are as yet far from possessing that knowledge of the internal functioning of animal societies which would be necessary to form an authoritative opinion on the subject of whether it is shared by animal societies. The annual slaughter of the drones in a beehive, once their usefulness and even potential usefulness is passed, appears to presuppose such a sense of reciprocity relationship on the part of the working bees. The great French physician D. -F. Arago ${ }^{55}$ tells the story of a dog who refused to take his place at the spit out of turn and consented to do so only after the dog whose turn it was had done his

ss CEuvres, pt. II, p. 66. 
duty. The dog, though doubtless unable to analyse his feelings, resented the suggestion of rendering a service which he felt not bound to perform and which he viewed as 'one-sided.' Again, wild elephants are known to choose and to follow a leader, but only so long as he is competent to fulfil useful functions. If he falls into an error, thus imperiling his troop, he is deposed and replaced by another. Dignity, honor, and prestige, which always go with leadership, require reciprocity, the concrete services expected of a leader. If these services are not performed or performed unsatisfactorily, the honors and the prestige are taken away..$^{6}$ Baron Ring, at one time minister plenipotentiary and consul general of France at Cairo, reports the story of a cat whom he had befriended and who effectively warned him of the presence of a poisonous snake concealed in the grass. ${ }^{57}$ What the author calls 'gratitude' is simply an awareness on the part of the cat that gifts (in the shape of choice morsels) somehow called for a service in return, to redress the balance of the reciprocity relationship.

Justice, then, requires the maintenance of a reciprocity relationship on an even keel. We speak of 'equal justice' when there is absolute equality between the two parties, i.e., when both enjoy equal rights. Needless to say, justice need not be 'equal' justice. There have existed, and there still exist, numerous societies whose members do not enjoy equal rights, but which are divided into social classes or castes, each having its own peculiar rights and privileges. In such societies there can be no 'equal' justice; but there can be justice nonetheless, if every class is given what is, according to the generally accepted view, its just 'due,' quite apart from the fact that even in such societies there exists 'equal' justice as between two members of one and the same class.

With the decay of feudalism in Europe the 'class State' made way for the modern democracy, in which all citizens enjoy equal rights and equal justice. This result of the great Whig revolution of I 688 has been generally accepted, and meant a great step in advance over the class State and class justice. What the makers of that revolution could not foresee was the coming into being of another form of inequality, produced by the industrial revolution of a century later, which was destined to reduce this equal justice under law in many cases to an empty mockery.

It has been increasingly felt, for example, that the reciprocity relation between employers of labor and wage-earners lacks that equilibrium which is deemed essential for harmonious relations between two parties, for the

${ }^{56}$ Touillée, Les éléments sociologiques de la morale I33 (I9\%5).

57 Ibid., I29, n. 2. 
excellent reason that this reciprocity relationship is not determined by principles of equity but, largely, by the purely economic law of supply and demand.

Above all, it was felt toward the beginning of the present century that in criminal legislation the principle of equality in a world full of glaring inequalities is apt to lead to the very reverse of justice, inasmuch as the Code, in the words of Anatole France, forbids rich and poor alike to steal apples and to sleep under bridges. ${ }^{58}$

All of which goes far to show that this reciprocity relationship, which is at the bottom of law and justice, is nothing stable, but is subject to fluctuations resulting from changes in the environment of a given society. Man does not live in vacuo but in a world which is in a constant flux and which is bound to react very unequally, at various times, upon man's reciprocity relations.

$5^{8}$ The realisation of the desirability of 'neutralising,' as it were, certain social inequalities by inequalities in the application of the law is fairly old. Thus in ancient Indian law theft committed by a man of a higher caste was punished more severely than the same crime committed by some poor devil of low birth; cf. Kohler and Wenger, op. cit., supra, note 27, vol. I, II4. 